\title{
ARCTIC AND SUBARCTIC EXAMPLES OF INTERTIDAL ZONATION
}

\author{
D. V. Ellis* and R. T. Wilce ${ }^{*}$
}

\section{Introduction}

D URING the last decade there has been an increasing interest in marine biological research in the Canadian North. We have been able to take part in this development, Wilce being mainly concerned with algal distribution and ecology in Labrador and Ellis with marine animals of the Canadian Arctic Archipelago. We noticed independently during our expeditions that intertidal animals and plants maintain patterns of vertical distribution, and in many places definite zones can be recognized. Our experiences have been pooled in this paper to describe some aspects of zonation on northern shores.

Intertidal zonation has been well studied in temperate and tropical regions, and a number of descriptive systems have been proposed for ease of classifying habitats and summarizing their populations (Doty 1957, Hedgpeth 1957). Of these the zonation scheme for rocky shores of Stephenson and Stephenson (1949) was applicable to the northern areas described here, but no equivalent scheme could be applied to the sedimentary shores (gravel, sand, or mud). The rocky shore observations have therefore been interpreted using the Stephensons' terminology of "mid-littoral zone, supra- and infralittoral fringes", but the sedimentary shore observations have been left unschematized.

This paper is based mainly on observations made during several expeditions in which Ellis took part. In 1953 he collected in Baffin Island, chiefly in Frobisher Bay and Cumberland Sound (Fig. 1), but also farther north (Ellis 1955). Subsequently in 1954, 1955, and 1957 he was able to investigate shores at Coppermine, Bathurst Inlet, Cambridge Bay, Spence Bay, Arctic Bay, Moffet Inlet, Pond Inlet, and Frustration Bay, Rowley Island, all on the northern mainland coast of Canada or in the Canadian Arctic Archipelago. Faunal collections and notes were made as intensively as possible, but unfortunately algal collections are unlikely to be as representative as is desirable.

*Fisheries Research Board of Canada, Biological Station Nanaimo, B.C., Canada.

$\nmid$ Botany Department, University of Massachusetts, Amherst, Mass., U.S.A. 
The main characteristics of the marine environment as it effects the intertidal zone of northern Canada can be summarized as follows. Surface water has marked annual cycles of temperature, salinity, and of other chemical and physical properties. The most recent demonstration of these is by Grainger (1959) in Foxe Basin. Surface salinities can fluctuate from 32 to $33 \%$ in winter to almost zero in summer in the "fjord water" surface layer (Thorson 1936). Surface temperatures fluctuate from about $-1.7^{\circ} \mathrm{C}$. (freezing point of water with a salinity of $32 \%$ ) in winter to as high as $5^{\circ} \mathrm{C}$. or higher in summer. In winter shallow sea-water is normally homothermous and

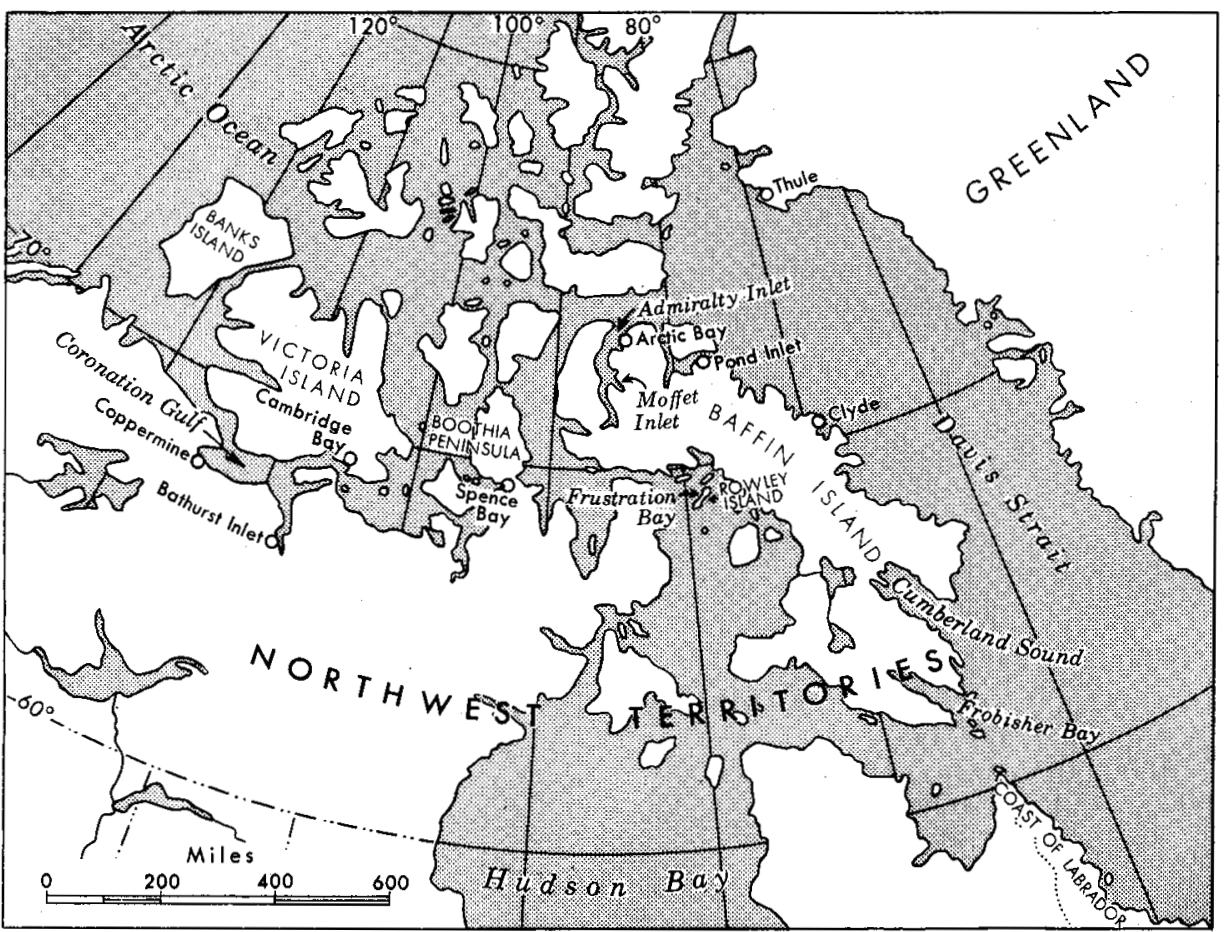

Fig. 1. Map of arctic North America showing localities mentioned in the text.

homohaline but in summer there may be abrupt, temporary, horizontal, and vertical temperature and salinity gradients. The southeastern section of the archipelago (southeastern Baffin Island), with which this paper is largely concerned, is slightly warmer and more saline than the more northerly regions. It lies in the subarctic regions as defined and described by Dunbar $(1951,1954$, and 1958). The subarctic marine fauna, including the intertidal populations, differs in composition from the true arctic fauna; the boundary between the two regions occurring at about latitude $66^{\circ} \mathrm{N}$. on the east coast of Baffin Island (Ellis 1955). 
Tidal amplitudes throughout the Canadian Arctic Archipelago are generally small, 1 to 3 metres (3 to 10 feet) being common (Anon. 1960). However, in southeastern Baffin Island the amplitude is very much greater. In Frobisher Bay, for instance, it may reach as much as 13 metres (40 feet). Tide tables for these regions are far from complete and this, combined with the rather primitive working conditions, made it impossible to fix standard tidal levels on any shore. The levels used in this paper, i.e., high-water springs (HWS), high-water neaps (HWN), mid-tide level (MTL), low-water neaps (LWN), and low-water springs (LWS) are therefore only approximate.

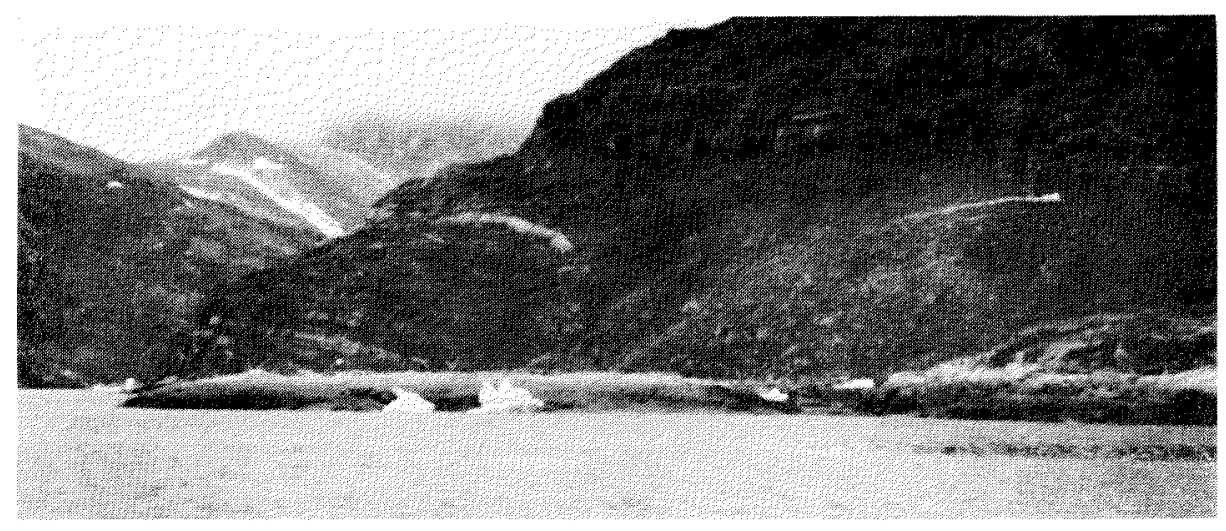

Fig. 2. On a rocky shore in Cumberland Sound, at low water, two coloured strips clearly show the extent of the intertidal area. An upper pale strip represents the supralittoral fringe that extends from slightly above HWS to below HWN. A lower darker strip represents the densely populated areas - the midlittoral zone and its lower border, the infralittoral fringe.

An important environmental feature of northern shores is the presence of sea-ice. Its ecological effects are described by the Stephensons (1954), who stress that intertidal populations are affected by both freezing and scouring. However, ice effects are modified by tidal amplitude (Ellis 1955). A narrow intertidal zone may be completely frozen at times or so intensively scoured at all tidal levels that it cannot support life for the greater part of the year. This situation is common in the Canadian Arctic Archipelago. However, if the intertidal zone is deeper than the maximum thickness of the local sea-ice, the lower levels of the shore may be abundantly populated. In such cases the upper levels are usually covered for many months each year by an icefoot, i.e., ice frozen solidly to the shore, whereas the lower levels are scoured by sea-ice at low water only and may not freeze at all. The shores of southeastern Baffin Island are of the last-named type.

The algae discussed in this paper were identified by R. T. Wilce and the animals by D. V. Ellis, with the exception of the polychaete worms, which were determined and described by E. H. Grainger (1954) of the Fisheries 
Research Board of Canada, Arctic Unit. Authorities for specific names are not quoted in this paper in view of its ecological nature, but are identical with those used previously by Ellis (1955 and 1960) and Wilce (1959). Financial support received from McGill University-Carnegie Arctic Scholarships, the National Research Council of Canada, and the Arctic Institute is here acknowledged.

\section{Moderately exposed rocky shores in southeastern Baffin Island}

The uppermost limit of marine plants on rocky ground sloping toward the sea consists of a dark zone of varying width, composed mainly of crustose lichens of the Verrucaria maura type. Immediately below this level, covering approximately the area between HWS and HWN, the rocks are barren and present a pale strip along the shore, sharply contrasting with darker zones above and below (Fig. 2).

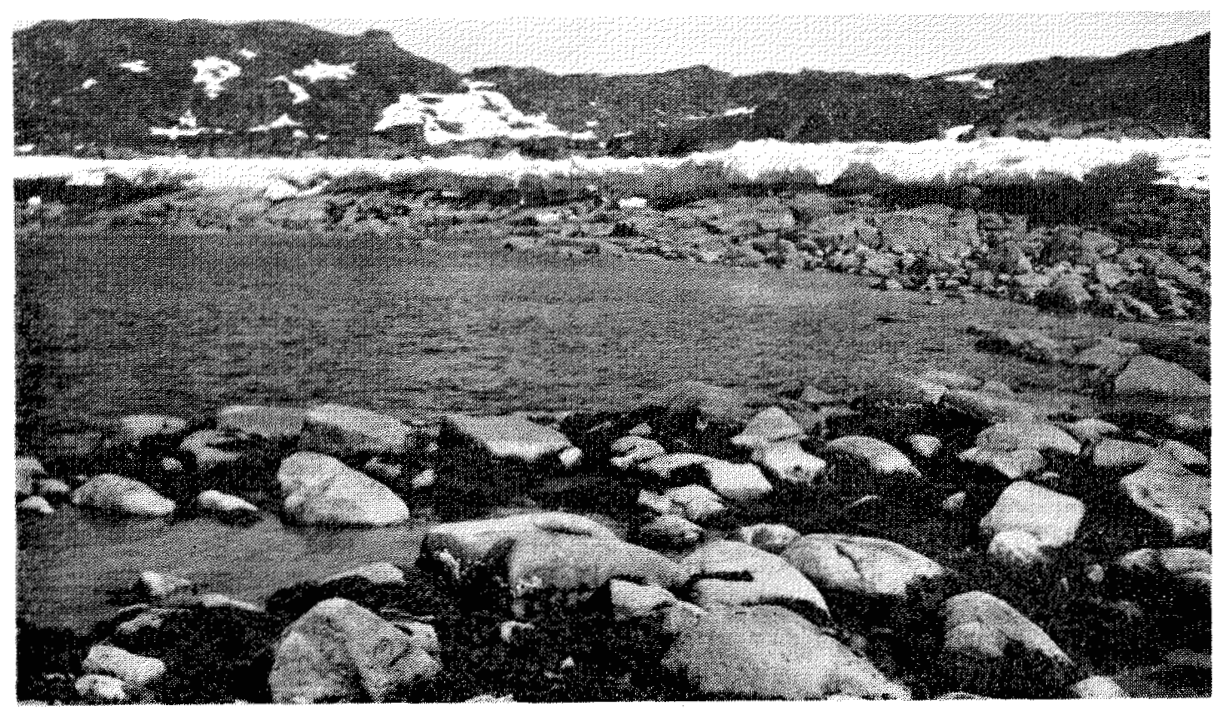

Fig. 3. On this rocky shore in Frobisher Bay, the distinction between dark and light strips is caused by a sharp upper limit to abundant fucoids slightly above MTL. Only stunted algae and Littorina saxatilis extend into the paler strip above. Even at MTL, and for some distance below, intertidal populations are restricted by ice scouring to the sides of rocks.

Below HWN, occupying the lower part of the pale strip, there occurs a zone of abundant Littorina saxatilis, mainly in cracks in the rock substratum, accompanied by meagre populations of severely stunted algae (Enteromorpha compressa and Urococcus foslieanus were collected) and a few amphipods, Gammarus setosus and G. zaddachi ssp. oceanicus. Rock 
pools and freshwater streams crossing the shore are scantily and monotonously populated in this area. The following species were collected:

$\begin{array}{lll}\text { Urococcus foslieanus } & \text { Prasiola crispa } & \text { Ralfsia fungiformis } \\ \text { Ulothrix pseudoflacca } & \text { Spongomorpha arcta } & \text { Fucus distichus ssp. evanescens. } \\ \text { Blidingia minima } & \text { Pylaiella littoralis } & \end{array}$

Lower on the shore, from above MTL to LWN, animals and plants occur more abundantly, forming the lower dark zone in Fig. 2. Barnacles, Balanus balanoides, and larger fucoids (Fucus vesiculosus, F. distichus ssp. distichus and $F$. distichus ssp. evanescens) are abundant at these levels in cracks, on the sides of rocks, and in any habitats not subject to intensive scouring by ice (Fig. 3). The upper surfaces of rocks and boulders are invariably quite barren. Frequently there is a white fringe of barnacles showing an inch or two above the uppermost algal populations. Species collected include:

Ulothrix pseudoflacca

Pringsheimella scutata

Prasiola crispa

Blidingia minima

Monostroma fuscum

Spongomorpha arcta

Spongomorpha lanosa

Pylaiella littoralis

Sphacelaria arctica

Sphacelaria radicans

Chordaria flagelliformis
Isthmoplea sphaerophora
Stictyosiphon tortilis
Fucus distichus ssp.
evanescens
Ptilota serrata
Rhodomela confervoides
Gemellaria loricata
Bunodactis stella

Harmothoe imbricata

Pseudalibrotus littoralis

Balanus balanoides

Musculus laevigatus

Crenella faba

Saxicava arctica

Margarita helicina

Margarita groenlandica

Littorina saxatilis.

On the lowest levels on the shore that are exposed only during spring tides a variety of other animals and plants, in addition to those listed above, were collected:

Chlorochytrium
dermatocolax*
Epicladia flustrae
Enteromorpha compressa
Enteromorpha intestinalis
Chaetomorpha
melagonium
Chaetomorpha linum
Chaetopteris plumosa
Ralfsia fungiformis
Lithoderma fatiscens
Elachistea fucicola
Litosiphon pusillus
Dictyosiphon
foeniculaceus

Laminaria saccharina
Laminaria groenlandica
Alaria grandifolia
Rhodochorton
$\quad$ penicilliforme
Rhodochorton purpureum
Halosaccion ramentaceum
Rhodymenia palmata
Polysiphonia arctica
Rhodomela confervoides
Alcyonidium gelatinosum
Lagisca rarispina
Eteone flava

Eteone longa

Spirorbis spirillum

Balanus crenatus

Mytilus edulis

Coryphella salmonacea

Acmaea testudinalis

Buccinum sp.

Stephanasterias albula

Ascidia callosa

Myoxocephalus scorpius

Myoxocephalus scorpioides

Liparis sp.

Gymnelis viridis.

*Endophytic in tissues of a Sphacelaria arctica and S. radicans.

At these levels L. saxatilis and B. balanoides disappear from the fauna. Many of the species are shallow-water forms, not normally found far up the shores, inhabiting permanently moist habitats, e.g., crevices covered with larger algae, rock pools, etc. Dredge hauls showed the presence of 
other shallow-water species below LWS, almost any of which can be expected to occur at times at the lowest levels on the shore:

Chlorochytrium inclusum*

Stictyosiphon subsimplex
Phyllophora interrupta

Polysiphonia arctica
Atylus carinatus

Gymnacanthus tricuspis.

*Endophytic in tissues of a variety of 'fleshy' Rhodophyceae.

The Laminariaceae listed were found in scattered pools and sublittoral beds, together with numerous smaller plants commonly associated with their holdfasts. One such colony taken from a drifting specimen between Frobisher Bay and Cumberland Sound included several species not seen elsewhere:

$\begin{array}{lllc}\text { Desmarestia aculeata } & \text { Euthora cristata } & \text { Odonthalia dentata } & \text { Phycodrys } \\ \text { Acrochaetium sp. } & \text { Antithamion boreale } & \text { Pantoneura baerii } & \text { rubens. }\end{array}$

Other shallow water algae were collected in southeast Baffin Island without records of their actual positions on the shores:

Entophysalis conferta Oscillatoria $s p$.

Xenococcus chaetomorpha

Chlorochytrium schmitzii*
Plinia sp.

Fucus distichus ssp. distichus

Fucus distichus ssp. evanescens.

*Crusts of brown algae.

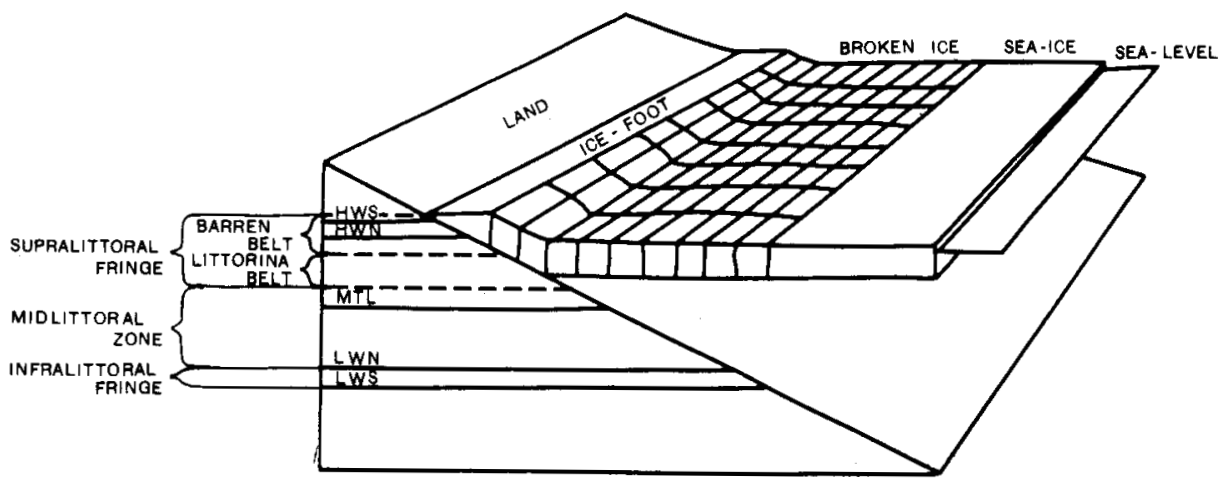

Fig. 4. Rocky shores in southeastern Baffin Island characteristically have a barnaclefucoid midlittoral zone, rather lower on the shore than in temperate regions, bordered by supralittoral and infralittoral fringes. The supralittoral fringe comprises an upper, wide, barren belt underneath the ice foot, and a lower Littorina belt. In this diagram sea-level is slightly below HWN. The ice foot is frozen solidly to the shore and is separated from the floating sea-ice, which moves vertically with the tides, by a strip of broken ice. This broken ice is responsible for much of the scouring to which arctic and subarctic shores are exposed.

The rocky-shore populations described here are found at rather lower levels than elewhere, as few animals or plants are found above MTL. Nevertheless, the intertidal zones established by the Stephensons can be recognized (Fig. 4). The lower half of the shore, dominated by barnacles 
and fucoids, is a typical midlittoral zone. Its upper limit is marked by the uppermost fringe of barnacles that lies slightly above the limit of dense algae, about in the region of MTL or slightly above. The higher Littorina belt and the uppermost barren belt together constitute the supralittoral fringe, which is here rather wider than usual as it extends from above HWS to almost MTL. Below the midlittoral zone, between LWN and LWS, the association of intertidal and sublittoral species, from which Littorina saxatilis and Balanus balanoides have disappeared, indicates the area of the infralittoral fringe. The abundance of species collected makes it seem probable that these zones and belts can be characterized by more species than we have been able to demonstrate.

\section{Sedimentary shores in southeastern Baffin Island}

On most shores composed of sediments the upper level of spring tides is recognizable by windrows of cast algae, once the shore-fast ice has broken up and drifted away. On all shores examined there is a barren zone (as far as marine animals and plants are concerned) extending from above the highest line of drying algae to well below the lowest.

Below the barren zone, around MTL, there are sparse populations of amphipods, with occasional polychaetes, lamellibranchs, and gastropods:

Harmothoe imbricata
Eteone longa
Capitella capitata
Arenicola marina
Scoloplos armiger

Harmothoe imbricata Eteone longa Capitella capitata Scoloplos armiger
Mya truncata

Cyrtodaria kurriana Myoxocephalus scorpioides Gymnacanthus tricuspis.

These species were occasionally found above MTL in pools.

Below MTL the shore first becomes noticeably populated, but as in the rocky-shore environment, it is only in the occasionally exposed area between LWN and LWS that a rich fauna is found. Animals from this area include:

Halcampa arctica
Amphiporus angulatus
Priapulus caudatus
Phyllodoce groenlandica
Eteone flava
Euchone analis
Eumenia crassa
Pista cristata
Leana abranchiata
Cirratulus cirratus

Halcampa arctica Amphiporus angulatus Priapulus caudatus Ophelia limacina Brada inhabilis Polydora caeca Pseudosabellides littoralis Ampharete grubei Spio filicornis Scalibregma inflatum Castalia aphroditoides Anonyx nugax Musculus niger

\author{
Astarte borealis \\ Astarte montagui \\ Axinopsis orbiculata \\ Macoma calcarea \\ Cylichna occulta \\ Onchidiopsis? sp. \\ Bela violacea \\ Leptasterias groenlandica \\ Myriotrochus rinki \\ Gymnelis viridis.
}

Most of these are shallow-water species found abundantly only below LWS. Dredge collections in shallow water during low-water spring tides revealed a few more species:

Sabella fabricii Nicolea zostericola
Amphitrite cirrata Serripes groenlandicum
Eumicrotremus spinosus. 
These, taken with the low shore populations, suggest the widespread occurrence of a Macoma level-bottom community (Ellis 1960) immediately below low water mark.

Algal populations are noticeably lacking and very poor in number of species represented. Usually algae are attached to rocks embedded in the substrate. Species collected include:

Sandy shores

Pylaiella littoralis

Sphacelaria arctica

Chaetopteris plumosa

Laminaria groenlandica
Fucus disticus ssp. evanescens

Fucus vesiculosus

Halosaccion ramentaceum

Polysiphonia arctica
Muddy shores

Spongomorpha arctica

Pylaiella littoralis

Elachistea fucicola

Halosaccion ramentaceum.

These were all collected below MTL. Although not present in the collections, it would not have been unexpected if at least one species of Vaucheria had been found, as this genus occurs in similar environments to the south (Blum and Wilce 1958).

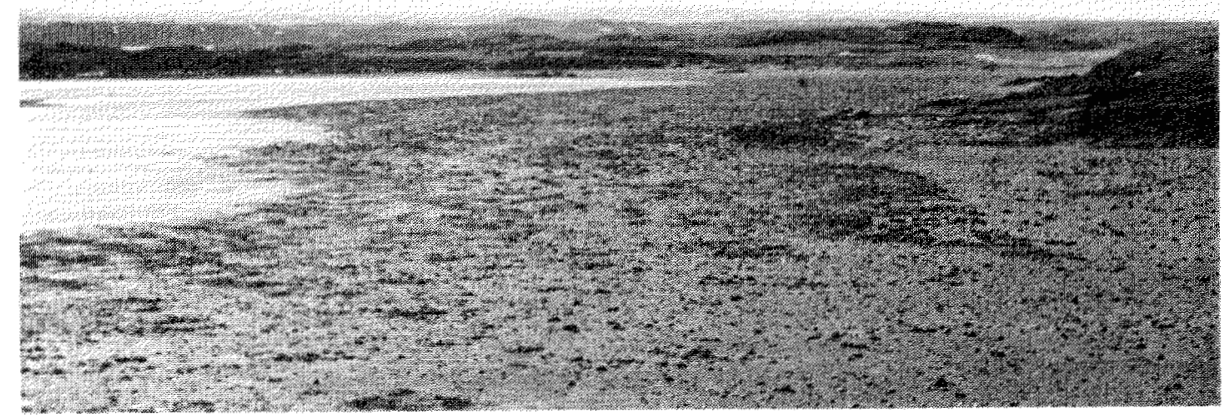

Fig. 5. Extensive sandy beaches at the head of Frobisher Bay support few animals above MTL, and only between LWN and LWS occur abundant populations.

Gravel, sand, and mud are the terms used to indicate sediments of decreasing coarseness. Gravel, where it occurs, is at the upper levels of the beaches and so is always barren. Different associations of species are found on sand and mud beaches. Thus, sandy beaches in Frobisher Bay (Fig. 5) support Halcampa arctica, Euchone analis, and Cyrtodaria kurriana, and in Cumberland Sound Arenicola marina, Cistenides granulata, Astarte borealis, Serripes groenlandicum, and Macoma baltica. These sand associations are in strong contrast to those on muddy beaches in Frobisher Bay (Fig. 6) that contain such species as Spio filicornis, Amphiporus angulatus, Harmothoe imbricata, Scoloplos armiger, and Capitella capitata.

In spite of faunal differences associated with different sediments, the vertical distribution of animals and what few plants were seen is essentially similar on all beaches examined, i.e., generally barren above MTL, sparsely 
populated in the lower part of the middle area, but gradually acquiring a fauna and flora as shallow-water forms become abundant, particularly below LWN.

\section{The Canadian Arctic}

The shores of true arctic regions are known to support very reduced populations and the observations made in 1954, 1955, and 1957 confirmed this for the central region of the Canadian Arctic. Between Coronation Gulf and Boothia Peninsula the only animals collected intertidally were occasional Mesidothea entomon at Coppermine and Gammarus setosus at Cambridge Bay. Both these species are mobile and must have arrived on the shores after the ice had melted in summer.

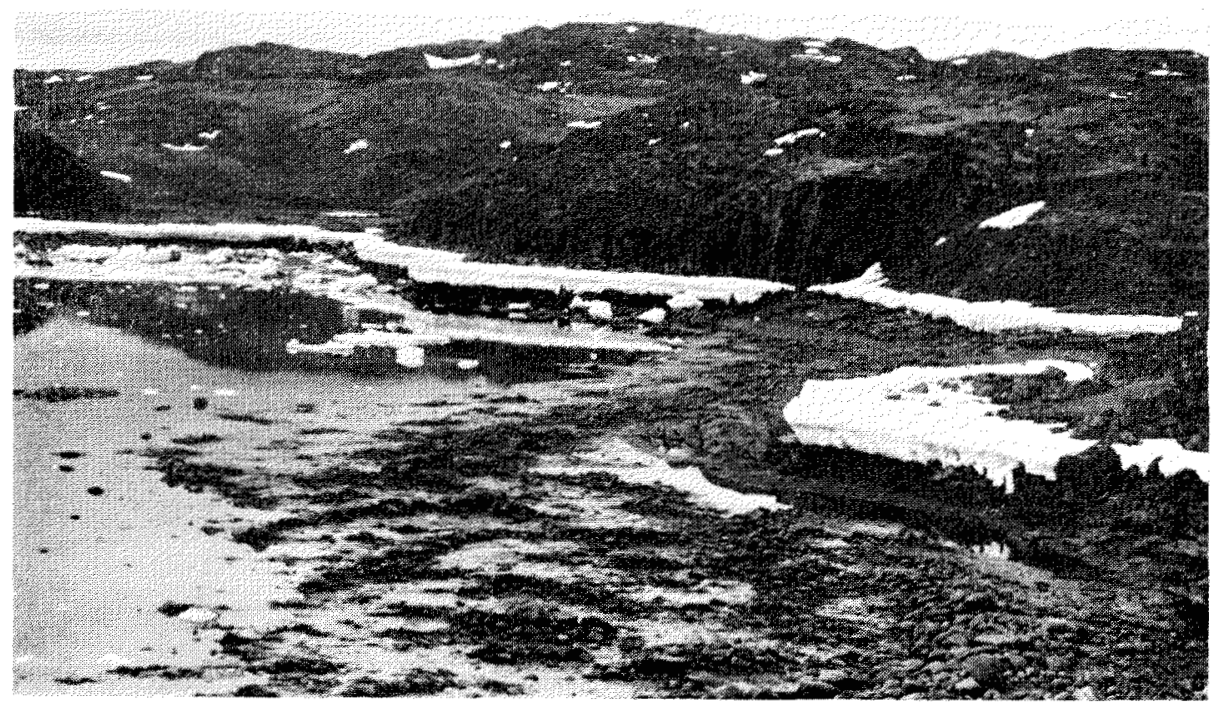

Fig. 6. This muddy beach in Frobisher Bay supports abundant populations below MTL. Most of the shore above MTL is bare rock and subject to freezing and scouring, and hence barren.

Several beaches were examined in Admiralty Inlet during the fall of 1954. Intertidal animals and plants were found at only one locality: a boulder beach on the south side of a small peninsula in Moffet Inlet at the mouth of a long, narrow subinlet through which raced violent tidal currents. The following species were collected under boulders or among small masses of Fucus near low-water-level:

Gammaracanthus loricatus Musculus corrugatus Myoxocephalus quadricornis. Gammarus setosus Tunicates

Musculus corrugatus and the tunicates are not mobile; there were too large to have been spawned that summer and must constitute a real inter- 
tidal population. This is apparently possible through the notoriously thin ice (thin for dog-sledging, that is) caused by the strong tidal currents. This thin ice does not prevent colonisation of the lower levels of the shore and a true intertidal population can develop.

At the mouth of the Salmon River near Pond Inlet settlement were accumulations of Mytilus edulis shells. Some of these contained undecomposed tissues, but attempts to find living colonies were unsuccessful. They may have existed subtidally, or have been destroyed fairly shortly before the area was visited, but there is a distinct possibility of an intertidal population of $M$. edulis in that area.

A few algae were collected from arctic sedimentary shores in Baffin Island during 1953. These included Chaetomorpha melagonium, Spongomorpha arcta, Pylaiella littoralis, Sphacelaria arctica, Chaetopteris plumosa, Chordaria flagelliformis, Stictyosiphon tortilis, and Desmarestia aculeata at Pond Inlet from near LWN on a gravel beach, and Calothrix scopulorum, Ulothrix pseudoflacca, Blidingia minima and Enteromorpha clathrata at Clyde near LWN on a gravel beach with sand patches and boulders.

\section{Discussion}

The examples of intertidal zonation described here present an outstanding feature, i.e., wide barren zones. On rocky shores the ice-foot covers a band from about HWS to between HWN and MTL, the width of which depends on the tidal interval. It almost corresponds to the barren belt, which however usually extends slightly above the upper level of the ice-foot. The barren belt probably arises mainly through ice action (freezing and scouring), but in summer wave action and perhaps the low salinity of fiord water will affect intertidal populations adversely. The thickness of ice appears to regulate the lower limit of the barren belt, and also influences the position of the Littorina belt, which is here decidedly lower than in temperate regions.

On sedimentary shores there is potentially a variety of habitats in the upper levels that could be populated by marine animals, e.g., algal debris, dry sand burrows, etc. These habitats either do not occur or are not inhabited on the shores that were examined. The upper levels of sedimentary shores are frozen solidly for many months of the year, and during the summer, especially when either freezing or melting occurs, they are subject to very severe scouring.

The barrenness of upper levels of northern shores must thus be largely due to ice action.

Intertidal zonation on the ice-scoured north coast of Prince Edward Island in the Gulf of St. Lawrence has been described by the Stephensons (1954). The shore populations are greatly reduced from normal, their dominant species are microphytic and encrusting algae, and they have peculiar morphological forms of common species. This relatively barren coast stands in marked contrast to the shores of southeastern Baffin Island, 
where the environmental conditions would seem to be more extreme. There the sea-ice is thicker and remains longer, but nevertheless the abundant shore life near low-water level is not even approximated by that of the north coast of Prince Edward Island.

The main reason for this difference in abundance of intertidal populations seems to lie in the relationship between tidal amplitude and thickness of sea-ice. In southeastern Baffin Island the amplitude is so great that on the lowest levels of the shore, ice neither freezes solidly to the land nor is the shore subject to continuous intensive scouring by ice. It is, therefore, possible for a rich shore population to develop in protected rock crevices and in the infralittoral fringe. On Prince Edward Island, which has coasts of soft, friable, uniformly stratified sandstone, a small tidal amplitude and ice thicker than the height of the intertidal area, animals and plants have very poor chances of survival. The extreme barrenness of the north coast of Prince Edward Island is a local phenomenon and should not be regarded as typical of northern shores in general.

Zonation is of course affected by the species present in the general area and the ease with which they can complete their life-cycles there. For instance, northward along the Atlantic coast from Labrador to the Canadian Arctic Archipelago there is a reduction in the number of plant species, their individual abundance, and the size of the individuals (Wilce 1959), and also in the number of specifically intertidal animals (Ellis 1955). These progressive population changes result in changes in the composition and density of intertidal zones and belts, one of the most drastic of which occurs at $66^{\circ} \mathrm{N}$. on the east coast of Baffin Island. Here, apparently, is the northern limit of the last two specifically intertidal animals, Littorina saxatilis and Balanus balanoides. Because intertidal species do not occur farther north the few localities where ice conditions permit intertidal colonization can be expected to have only much reduced populations that are similar to those found in Moffet Inlet (see p. 232), and previously at Thule (Vibe 1951).

Sedimentary shores of sand and mud are unusual in the Canadian Arctic Archipelago and those that were investigated are populated only by mobile sublittoral animals, and a few species of algae. Populations of sandy and muddy shores appear to be very rare and much reduced.

\section{Summary}

Populations on rocky shores in arctic and subarctic regions of eastern arctic North America exist only where thickness of shore ice is less than the tidal amplitude.

Subarctic populations show patterns of zonation fitting into the descriptive scheme suggested by Stephenson and Stephenson (1954). They have, characteristically, a midlittoral zone dominated by Balanus balanoides and fucoids, bordered by infralittoral and supralittoral fringes. The infralittoral fringe is abundantly populated by shallow-water species. The other 
commonly consists of two belts: an upper barren belt kept clear of sedentary animals and plants principally by ice frozen solidly to shore each winter, and a lower Littorina belt sandwiched between the barren belt and the barnacle-fucoid midlittoral zone.

Populations on arctic rocky shores are rare and limited to low levels.

Populations on subarctic sedimentary shores generally exist only below mid-tide level due to the lethal effects of freezing and ice scouring on upper levels. These populations occur sparsely near mid-tide level, becoming abundant only near low-water level.

Populations on arctic sedimentary shores are very rare and much reduced.

\section{References}

Anon. 1960. Atlantic coast tide and current tables 1960. Can. Hydrogr. Serv. Tidal Publ. No. 1, 274 pp.

Blum, J. L., and R. T. Wilce. 1958. Description, distribution and ecology of three species of Vaucheria previously unknown from North America. Rhodora 60:283-8.

Doty, M. S. 1957. Rocky intertidal surfaces. Mem. Geol. Soc. Am. 67:535-85.

Dunbar, M. J. 1951. Eastern arctic waters. Bull. Fish. Res. Bd. Can. 88, 131 pp.

7:213-28.

1954. Arctic and subarctic marine ecology: immediate problems. Arctic

1958. Physical oceanographic results of the Calanus expeditions in Ungava Bay, Frobisher Bay, Cumberland Sound, Hudson Strait and northern Hudson Bay, 1949-1955. J. Fish. Res. Bd. Can. 15:155-201.

Ellis, D. V. 1955. Some observations on the shore fauna of Baffin Island. Arctic 8:224-36. 1960. Marine infaunal benthos in arctic North America. Tech. Paps. Arctic Inst. N. Am. No. 5, 53 pp.

Grainger, E. H. 1954. Polychaetous annelids of Ungava Bay, Hudson Strait, Frobisher Bay and Cumberland Sound. J. Fish. Res. Bd. Can. 11:507-28.

1959. The annual oceanographic cycle at Igloolik in the Canadian Arctic.

I. The zooplankton and physical and chemical observations. J. Fish. Res. Bd. Can. $16: 453-501$.

Hedgpeth, J. W. 1957. Sandy beaches. Mem. Geol. Soc. Am. 67:587-608.

Stephenson, T. A., and A. Stephenson. 1949. The universal features of zonation between tide-marks on rocky coasts. J. Ecol. 37:289-305.

1954. Life between tide-marks in North America. III. Nova Scotia and Prince Edward Island. J. Ecol. 42:14-70.

Thorson, G. 1936. The larval development, growth and metabolism of arctic marine bottom invertebrates. Medd. om Grnl. 100, No. 6, $155 \mathrm{pp}$.

Vibe, C. 1950. The marine mammals and marine fauna in the Thule district (Northwest Greenland) with observations on ice conditions in 1939-41. Medd. om Grnl. 150 , No. 6, 115 pp.

Wilce, R. T. 1959. The marine algae of the Labrador peninsula and northwest Newfoundland (ecology and distribution). Bull. Natl. Mus. Can. 158, 81 pp. 